\title{
Studio Teaching Mode, Innovation and Practice of Fostering Creative Design "Dream Works" Talent
}

\author{
Xufen Huang ${ }^{1} \&$ Shouzhong $\mathrm{Hu}^{2}$ \\ ${ }^{1}$ College of fashion, Shanghai University of Engineering Science, Shanghai, China \\ ${ }^{2}$ College of fashion, Shanghai University of Engineering Science, Shanghai, China \\ Correspondence: Xufen Huang, Costume Institute, Shanghai University of Engineering Science, Shanghai, China. \\ E-mail: 631459358@qq.com
}

Received: October 21, 2014

Accepted: November 3, 2014

Online Published: January 26, 2015

doi:10.5430/jbar.v4n1p12

URL: http://dx.doi.org/10.5430/jbar.v4n1p12

\begin{abstract}
In order to achieve the training aim of fashion creative talent and reform the teaching model of creative design .Shanghai University of Engineering Science College of fashion integrate concept of "Dream Work" into creative garment design excellent education by exploring the teaching mode of training creative talents, building professional teaching studio groups and carrying out teaching research project actively to ensure effective implementation of creative design based on inheriting industry-university and school-enterprise in SUES.
\end{abstract}

Keywords: Studio teaching mode, Artistic talent

\section{The demand of teaching reform of costume design talents}

Creative industry has become the one of the key strategic transformation of economic development model in Shanghai, Although the development of creative industry offer the opportunity for speeding up traditional textile industry. The creative industry of Shanghai still meet with many difficulties, many distinctive industrial parks have to faced the predicament of no enough talents when completed. Lacking of top creative talents and creative teams have become the bottleneck that restrict the further development of the industry. Importing and assimilating the creative process and creative design management experience of "Dream Work integration" (Note 1) from American, Shanghai have promote creative industry integrated into the world creative culture pace gradually. The aim of "Oriental Dream Work" created in Shanghai is to make Shanghai creative design starting from China and entering the international market.

The model of "Creative Garment Design Studio personnel training" in Shanghai University Of Engineering Science (referred to as SUES) is that based on inheriting industry-university and school-enterprise in SUES, reference the talents education and cultivation in well-known clothing design in domestic and foreign, And the integration concept of combining "Art, Technology" in creative design "Dream Work" and "Creative, Practice", integrate into excellent education of garment creative design, actualize the training objectives and specific implementation of the nation Ministry of education" Outstanding Engineers Plan", rely on the interactive platform that combined "Shanghai creative product design engineering technology research center", Shanghai textile research institute (graduate, undergraduate) joint training practice basement" and "creative design studio", build garment design creative teaching platform of creative design studio and the practical teaching model of curriculum project system, the application specialty that combined fashion design ,garment engineering, apparel sale with teaching, business practice, the integration of "Art, Technology" and the integration of "scientific innovation, creative art", achieving the training aim of fashion creative talent of clothing excellence engineers and the development model of innovation and creative design teaching reform.

\section{Training status of clothing creative design talent in Shanghai}

The period of "Twelve Five" is the strategic opportunities for the development of creative industry in Shanghai. February 2010 UNESCO approved Shanghai adding "Creative City Network" and issued a title that "Design" for Shanghai. At present, Shanghai has established 85 creative industry gathering area, including M50, the 8th bridge, Tianzifang, industrial park and other famous fashion park. In recent years, Shanghai has adjusted the development strategy of textile and clothing gradually, that from the traditional manufacturing and processing model to adjust to development strategy based the new fabric development, brand marketing planning and creative design, thus 
shortage of creative design talents will become the future of the apparel industry, its innovation and training are very important.

At present, China's garment higher technical education cannot meet the actual needs of the apparel industry development, in the field of fashion design, which is require a lot of innovative art and design talent that comprehensive, integrated capabilities. Strengthen exercises that conducting overall quality by practical teaching of studio is a effective training model that culture innovation art talent.

In Europe, the design art school attaches great importance to costume design practice of teaching, and the studio project - practical teaching occupies an important position. In recent years, there has appeared various types of studio associated with clothing education in society, including the studio that schools collaborate with businesses, the platform built by government, the studio created by industry institute and established by the instructor and expert. They are extension and continuation to conventional teaching and embodiment of innovation teaching model. Establishing the teaching model of the studio that under instructors'responsibility, conducting the practical teaching of integration of professional course, and questing the excellence education of the training model that clothing creative studio combined with the actual production of social.

\section{Excellent education system and content of clothing creative design talent}

\subsection{Exploring the teaching mode of training creative talents based on design studio}

Exploring the establishment of creative design and management methods, establishing a teaching, research, practice trinity education model gradually, forming system of classroom, studio - society in practice settings.

Exploring the personnel training mode of the intersection of different disciplines regroup, The creative design disciplines are currently showing obvious tendency of permeating and combination of art and crafts, It is the inevitable trend to promote the development of creative design that combine of science and art.

Exploring the creative design of educational methods course project, Strengthening the design course in the teaching application project. And actively organize the students to full participate with social practice project in creative design studio.

Actively exploring the "Enterprise Project teaching.", students are directly involved in the project design practice under the instruction of teachers, according to the enterprise operation mode students perform some special design in the real market conditions, Enable students to fully experience the market environment, and creative problem-solving issues faced.

\subsection{Building professional teaching studio group}

Constructing creative design studio group of fashion products and clothing marketing, Including "clothing fashion creative design studio", "fabric creative design studio", "marketing e-commerce and fashion clothing brand planning studio", "clothing accessories creative design studio", "creative textile design studio" and so on, Each studio as the basic framework build teaching group to form an interconnected, network-like distribution of teaching knowledge platform.

In the studio work, students are trained with real project. The students have the right to choose the studio, in order to improve student learning initiative the teacher can set a certain threshold and carry out elimination system.

In fact, the implementation of student innovation fund project and teacher studio project also is the start-up of creative incubator factory professional in schools, It not only can solve the learning difficult of the combination of engineering and learning and practical difficulties of less internship positions, but also encourage a group of students and teachers to produce measurable work(See Table 1).

\subsection{Engineering room teaching mode to provide support and guarantee for the practice of creative design}

Creative practice is the fundamental means to cultivate high level innovative talents. The undergraduate level talents training has already transformed from emphasize on teaching to foster innovation ability, By "studio" school enterprise interaction will broaden the field of teaching practice, increase sources of studio practice project. We have long-term research partnership with Shanghai Textile Holding Company, Shanghai Garment Institute, Tahui knitwear company, and Heng Yuan Xiang clothing company, These "studio" extended to off-campus practice sites not only provide students with visits, internships, cooperative education and other bases, But also with the discipline of fashion design, brand planning develop horizontal cooperation project provide a broad space for students to enter the studio to complete the project courses. 


\subsection{Carrying out teaching research project actively and ensure effective implementation of creative design}

Teaching research is the key measure to explore the teaching mode and improve teaching methods, Creative design studio is a new mode of practice teaching. In the U.S, Europe, Japan and other developed countries, the studio education is an effective way of integrated teaching in art and design education. The teaching innovation result on the basis of creative design studio actively explore the practice teaching mode, develop kinds of the practice teaching research project and publish appropriate teaching materials and research in order to improve the cultivation of creative fashion design talents effectively.

Table 1. studio specific work and research Introduction

\begin{tabular}{|c|c|c|}
\hline Studio Name & The main work contents & Practice Teaching \\
\hline $\begin{array}{l}\text { Clothing fashion } \\
\text { creative design } \\
\text { studio }\end{array}$ & $\begin{array}{l}\text { (1) Clothing creative design } \\
\text { (2) Clothing construction design } \\
\text { (3) Advanced customization } \\
\text { (4) Garment design } \\
\text { (5) Garment design and production }\end{array}$ & $\begin{array}{l}\text { As the practice teaching courses for clothing } \\
\text { creative design, special design, knitting } \\
\text { design. }\end{array}$ \\
\hline $\begin{array}{l}\text { Fabric creative } \\
\text { design studio }\end{array}$ & $\begin{array}{l}\text { (1) Creative design pattern } \\
\text { (2) Fabrics Creative Design }\end{array}$ & $\begin{array}{l}\text { As the practical teaching base for digital } \\
\text { fabric design and hand-dyeing, fabric effect, } \\
\text { dress patterns and other courses }\end{array}$ \\
\hline $\begin{array}{l}\text { Clothing creative } \\
\text { Exhibition practice, } \\
\text { Marketing, } \\
\text { e-commerce } \\
\text { platform studio }\end{array}$ & $\begin{array}{l}\text { Brand planning simulation experiment } \\
\text { Merchandise planning simulation experiment } \\
\text { Marketing promotion simulation experiment } \\
\text { Exhibition planning simulation experiment }\end{array}$ & $\begin{array}{l}\text { As a set of practice teaching courses for } \\
\text { fashion bands, Clothing sales planning, } \\
\text { Fashion show and exhibition and other } \\
\text { courses }\end{array}$ \\
\hline $\begin{array}{l}\text { Garment } \\
\text { accessories creative } \\
\text { design studio }\end{array}$ & $\begin{array}{l}\text { Shoes and hats creative design } \\
\text { Accessory Design } \\
\text { Jewelry design }\end{array}$ & $\begin{array}{l}\text { for clothing accessories design and special } \\
\text { design course }\end{array}$ \\
\hline
\end{tabular}

\section{To promoting and improving the creative design talent studio teaching mode}

Shanghai is in the level of improving economic performance, adjusting and optimizing the industrial structure. The creative design industry orientation should not be underestimated in Shanghai's social and economic development. Especially, garment industry has become an important branch of creative industry, The new fashion industry is taking shape, For the advanced creative design talent in great demand. Creative design studio practice teaching is an effective way to cultivate creative fashion talent under the new situation in accordance with the strategic planning for shanghai creative industry, The teaching mode of creative design studio is a application of innovative education mode to meet the students' creative design thinking and Cultivation of "learning by doing", this teaching mode contributes to interact between schools and outside school teaching resources united, increase mutual cooperation opportunities between production and education, promote the scientific research project effectively, Students can participate design activities in the design studio, this teaching mode provide design practice base for students and combines teaching, design, practice three links as a whole, The teaching mode of creative design studio can highlight creative industries growth mechanism of talent fusing skills applied creative design featuring and the creative industries, Allows students to directly participate in the creative production, they can direct contact with the media at the forefront and expand horizons, Greatly improve the professional level of application, making the talent cultivation plan, teaching content and practice link closer to the needs of social development.

Mature development of creative industries is built on the basis of the height of the discipline, professional education. The key of the cultivation of innovative talents of creative design lies in the innovation of higher education and creative design professional disciplines itself, while the philosophy, mode and education training mechanism innovation is the most important step. So the exploration of excellent education action research on the implementation of creative fashion design talent is the important opportunity to deepen the reform of personnel education teaching creative design and for innovative training model. Simultaneously, In the context of large-scale 
development of creative industries, how to change from traditional education to modern design education which focusing on creative thinking and mental spirit, this problem has an important theoretical and practical significance.

After several years of successful practice of teaching reform and innovation, It gets recognition from society with clothing creative design studio, research group gradually improved, for example, it approved by the Shanghai Municipal Science and Technology Commission as "Shanghai creative product design engineering technology center (Creative Garment Design Platform)"in 2012 and approved as "Shanghai Creative Garment Design and digital technology in public service platform" in 2013, These will effectively encourage the further improve of creative design studio construction and practice teaching mode and better promote students' practical ability and overall quality in order to achieve the purpose of fostering a culture of creative talent and forming growth mechanism of creative talents and the promotion of model.

\section{Acknowledgements}

This study was funded by Science Technology Commission of Shanghai Municipality, the funded project No.B14035 and Municipal Education Commission of Shanghai, the funded project No.13ZS128. And this study was supported by graduate innovation fund of shanghai university of engineering science university, the funded project is No.E1-0903-14-01155"Reserch on clothing digital distribution logistics management system based on RFID technology" And No.E1-0903-14-01172 "Study of cluster brand development strategy of Shanghai "dragon" group".

\section{References}

Chen, D. S. \& Gan, Y. J. (2010). Art Engineering Featured Clothing Professional Training Model And Objectives Analysis. Chinese University Teaching, 2, 31-34.

Curry, SJT. (2014). A theoretical basis for recommending the use of design methodologies as teaching strategies in the design studio. http://dx.doi.org/10.1016/j.destud.2014.04.003

Han, ZJ , Yuan, LY, Gao LQ. (2013). Research on College Students' teaching mode based on the subject contest. International Conference on Advances in Social Science, Humanities, and Management. 43.653-656. http://dx.doi.org/10.2991/asshm-13.2013.122

Hu, S. Z. (2012). Social Interactive Creative Design Education. In: shanghai, International Fashion Forum - the creative industries and fashion education.

Li, D. Y. (2010). The Survey Of Clothing Industry And Clothing Higher Education In Shandong. Jinan textile, 1, 7-13.

Lin W. (2010). China art talent cultivation, the demand condition and countermeasures research. Journal of Hubei Normal University. 3.125-129.

Ling J.B, Wu AB, Tan Z. (2012). Strategy exploration on the cultivation of innovative talents in Universities of art under the educational policy. Journal of HeFei University of Technology. 6.138-142.

Shraiky, JR. Lamb, G. (2013). Studio-based learning in interprofessional education. http://dx.doi.org/10.3109/13561820.2013.816273

Yang Q. H. (2011). Model on training college art talents in the new period. The voice of the Yellow River. 2. 56-57.

Zhang C. P. (2013). The contemporary university art personnel training deficiencies and optimization strategy. Chinese talent. 6.183-184.

\section{Notes}

Note 1. Dream Works (full name: Dream Works Studios) is an American firm which does film processing, production and distribution ranked in the top ten. Meanwhile, It is a video game, TV program production company. Based on the huge digital film exclusive resources, this film strives to build a comprehensive program including stars, entertainment, star and information. 